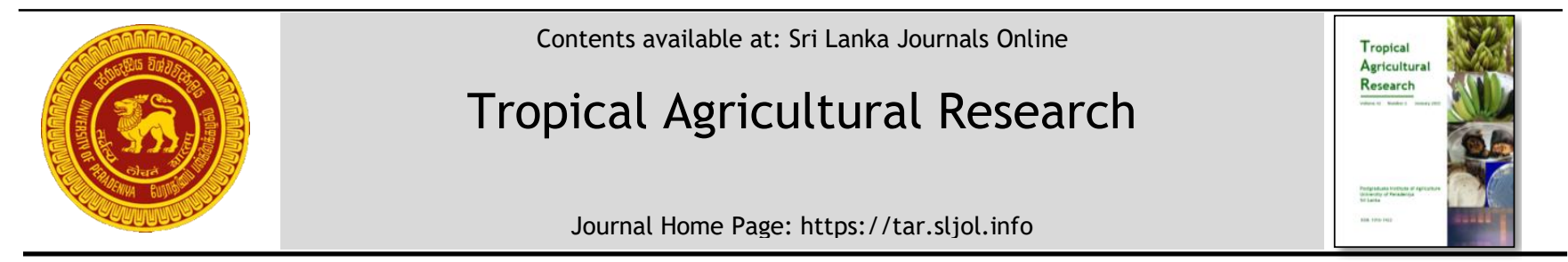

\title{
Antioxidant Efficacy of Selected Underutilized Fruit Species Grown in Sri Lanka
}

\author{
M.A.L.N. Mallawaarachchi ${ }^{1}$, T. Madhujith ${ }^{2 *}$, L.D.B. Suriyagoda ${ }^{3}$ and D.K.N.G. Pushpakumara ${ }^{3}$ \\ ${ }_{1}^{1}$ Postgraduate Institute of Agriculture, University of Peradeniya, Peradeniya, Sri Lanka. \\ ${ }^{2}$ Department of Food Science and Technology, Faculty of Agriculture, University of Peradeniya, Peradeniya, Sri Lanka. \\ ${ }^{3}$ Department of Crop Science, Faculty of Agriculture, University of Peradeniya, Peradeniya, Sri Lanka.
}

\section{ARTICLE INFO}

\section{Article history:}

Received: 18 July 2020

Revised version received: 09 October 2020

Accepted: 05 November 2020

Available online: 1 January 2021

\section{Keywords:}

Antioxidant efficacy

Total anthocyanin content

Total phenolic content

Underutilized fruit crop species

Vitamin C content

\section{Citation:}

Mallawaarachchi, M.A.L.N., Madhujith, T., Suriyagoda, L.D.B. and

Pushpakumara, D.K.N.G. (2021).

Antioxidant Efficacy of Selected Underutilized Fruit Species Grown in Sri Lanka. Tropical Agricultural Research, 32(1): 68-80.

DOI: http://doi.org/10.4038/tar.v32i1.8443

Mallawaarachchi, M.A.L.N

https://orcid.org/0000-0002-4505-1026

\section{ABSTRACT}

The present study was carried out to determine the vitamin $\mathrm{C}$ content, total phenolic content (TPC), antioxidant efficacy and total monomeric anthocyanin content (TMAC) of twenty-one underutilized fruit species grown in Sri Lanka. Approximately 5 $\mathrm{g}$ of fruit homogenates was used to determine the vitamin $\mathrm{C}$ content while lyophilized aqueous extracts were used to perform in-vitro antioxidant assays. Folin-Ciocalteu's colorimetric assay was used to determine TPC. The 2,2-diphenyl-1-pycrylehydrazyl (DPPH) radical scavenging, 2,2'- azinobis- 3ethylbenzothiazoline-6-sulphonic acid (ABTS) total antioxidant activity and ferric reducing antioxidant power (FRAP) assays were used to determine antioxidant efficacy of fruit extracts, while the $\mathrm{pH}$ differential method was used to determine TMAC. The highest TPC (104 mg of gallic acid equivalents/g on dry weight (DW) basis), reducing power (155 $\mu$ mol of ferrous sulphate equivalents/g DW), and the lowest $\mathrm{IC}_{50}(0.0004 \mathrm{~g}$ of $\mathrm{DW} / \mathrm{mL}$ ) were recorded in Phyllanthus emblica and obtained the first rank in overall antioxidative properties among the tested fruit species. Fruits with the highest total antioxidant activity were Flacourtia indica, Morus alba, Phyllanthus emblica and Syzygium caryophyllatum. The highest TMAC was found in $S$. caryophyllatum (79 mg of cyanidin-3-glucoside (C3G)/g DW) and the lowest in Elaeocarpus. serratus (0.29 mg C3G/g DW). Results obtained in this study can be used as baseline data to carry out further research and formulation of food compositional tables. The underutilized fruit species tested could be used as sources of natural antioxidants in nutraceuticals and in novel food product development.

*Corresponding author : tmadhujith@agri.pdn.ac.lk 


\section{INTRODUCTION}

A mounting volume of epidemiological evidences exist to the effect that intake of fruits and vegetables is inversely related to the risk of chronic diseases such as cancer, coronary heart diseases, atherosclerosis (Brecht et al., 2008), inflammation, brain dysfunction and arthritis (Leong and Shui, 2001). This inverse relationship between fruit and vegetable consumption and disease incidences is believed to be due to the presence of a plethora of phytochemicals bearing antioxidative properties (Heinonen and Meyer, 2002), which are synthesized in plants as an adaptation to physical, biological and chemical challenges such as pest and disease incidences, water loss and extreme temperatures (Brecht et al., 2008). These antioxidative compounds present in plants such as flavonoids, phenolic acids, tocopherols, ascorbic acid and carotenoids protect plants from oxidative stress and various other stresses by acting as free radical scavengers, metal chelators, hydrogen donors, singlet oxygen quenchers and reducing agents (Rice-Evans et al., 1997). Plants being major parts of the human diet, these phytochemicals present in them contribute to protect human body from various free radical induced chronic diseases. Among thousands of phytochemicals present in plant matrix, phenolic acids and flavonoids are considered the most widely distributed antioxidants (Rice-Evans et al., 1997).

Anthocyanins, one of the major groups of flavonoids present in the vacuolar sap of the coloured plant parts and fruits (Manach et al., 2004). Those possess various health benefits including anti-inflammatory, anticancer, antidiabetic properties, among others (Rossi et al., 2003). Among six types of anthocyanidins present in food, cyanidin is the most common (Manach et al., 2004).

Vitamins C, E and carotenoids are believed to have antioxidant activities via multiple mechanisms (Rutkowski and Grzegorczyk, 2007). Vitamin C reduces the risk of arteriosclerosis, cardiovascular diseases and some forms of cancer (Lee and Kader, 2000).

Being a tropical country, Sri Lanka is rich in plant diversity. Many of the plants are with food uses and also used in traditional medicine, while these fruit plants play a vital role in the diet of low-income groups. However, their antioxidant potential is not fully exploited, thus records are scanty in literature. In this light, the present study was conducted to evaluate antioxidant efficacy of twenty-one underutilized fruit species grown in Sri Lanka.

\section{METHODOLOGY}

\section{Fruit Samples}

Healthy and ripe fruits of twenty-one underutilized fruit species from fifteen plant families (Table 1) were collected from the Fruit Research and Development Institute, Horana, and home gardens in Upcountry Intermediate Zone of Sri Lanka (IU3). The collected fruit samples during the peak production period of the years of 2013 and 2015 were transported to the analytical laboratory of the Regional Agriculture Research and Development Centre, Bandarawela, under cold conditions, sorted for defects, washed with running tap water, rinsed with distilled water, drained at room temperature (RT) to remove surface water, and photographed. Their skin colour was determined using the RHS colour chart (sixth edition 2015) whereas the flesh colour was determined in Aegle marmelos, Dialium ovoideum and Limonia acidissima. One kilogram of each fruit species was taken to extract the edible portion and homogenized. Forty grams and five grams of each homogenate were taken to extract phenolic compounds and to determine vitamin $\mathrm{C}$ content, respectively.

\section{Chemicals and Reagents}

All chemicals and reagents used in the study were of analytical grade.

\section{Sample Extraction}

Forty grams of the homogenate of each fruit was extracted with $120 \mathrm{~mL}$ of distilled water for 90 minutes at $150 \mathrm{rpm}$ on a reciprocating shaker, and centrifuged $(2,750 \mathrm{~g})$ for 10 minutes. Then the supernatants were collected separately, and the extraction was repeated twice more. Collected supernatants were combined, lyophilized at -50 ${ }^{\circ} \mathrm{C}, 24 \mathrm{mbar}$ for $96 \mathrm{~h}$ and subsequently stored at $-20{ }^{\circ} \mathrm{C}$ until further analysis.

\section{Sample Preparation}

To perform 2,2-diphenyl-1-picrylhydrazyl hydrate (DPPH) radical scavenging assay six different concentrations of each sample ranging from 0.5 to $10 \mathrm{mg} / \mathrm{mL}$ were used. In order to carry out other in-vitro assessments for antioxidant efficacy (i.e., total phenol and anthocyanin content), samples were prepared to have a final concentration of 4 $\mathrm{mg} / \mathrm{mL}$. All assays were carried out in six replicates. 
Table 1: Selected fruit species

\begin{tabular}{|c|c|c|c|c|}
\hline & Selected Fruit Species & Plant Family & $\begin{array}{c}\text { Local (S)/ English (E) } \\
\text { Names }\end{array}$ & Fruit Colour \\
\hline 1 & Aegle marmelos L. Corr. Serr. & Rutaceae & $\begin{array}{l}S: \text { Beli } \\
E: \text { Bael fruit }\end{array}$ & $\begin{array}{l}\text { Orange group N25-D } \\
\text { (flesh) }\end{array}$ \\
\hline 2 & Averrhoa bilimbi L. & Oxalidaceae & $\begin{array}{l}S: \text { Bilin } \\
\text { E: Bilimbi }\end{array}$ & $\begin{array}{l}\text { Yellow-green group } \\
145-\mathrm{A}\end{array}$ \\
\hline 3 & Averrhoa carambola L. & Oxalidaceae & $\begin{array}{l}S: \text { Kamaranga } \\
E: \text { Star fruit }\end{array}$ & $\begin{array}{l}\text { Yellow-green group } \\
154-C\end{array}$ \\
\hline 4 & $\begin{array}{l}\text { Baccaurea motleyana (Mull. Arg.) } \\
\text { Mull. Arg. }\end{array}$ & Euphorbiaceae & $\begin{array}{l}\text { S: Gaduguada } \\
\text { E: Rambai }\end{array}$ & $\begin{array}{l}\text { Yellow-orange group } \\
16-\mathrm{D}\end{array}$ \\
\hline 5 & Carissa carandas L. & Apocynaceae & $\begin{array}{l}\text { S: Maha-karamba } \\
\text { E: Ceylon Damson }\end{array}$ & $\begin{array}{l}\text { Grayed-purple group } \\
\text { N186-B }\end{array}$ \\
\hline 6 & Cordia dichotoma G. Forst. & Boraginaceae & $\begin{array}{l}\text { S: Lolu }(\text { Yolu }) \\
\text { E: Indian Cherry }\end{array}$ & Orange group 27-C \\
\hline 7 & Cynometra cauliflora Linn. & Fabaceae & $\begin{array}{l}\text { S: Nami-nam } \\
\text { E: Nam Nam }\end{array}$ & $\begin{array}{l}\text { Grayed-brown group } \\
\text { N199-D }\end{array}$ \\
\hline 8 & $\begin{array}{l}\text { Dialium ovoideum (Kunth) } \\
\text { Baehni }\end{array}$ & Fabaceae & $\begin{array}{l}S: \text { Gal-siyambala } \\
E: \text { Velvet Tamarind }\end{array}$ & $\begin{array}{l}\text { Grayed-orange group } \\
164-B \text { (flesh) }\end{array}$ \\
\hline 9 & $\begin{array}{l}\text { Diospyros discolor (Willd.) nom. } \\
\text { Illeg }\end{array}$ & Ebanaceae & $\begin{array}{l}S: \text { Thimbiri } \\
E: \text { Velvet apple }\end{array}$ & Red group 43-C \\
\hline 10 & Elaeocarpus serratus Linn & Elaeocarpaceae & $\begin{array}{l}S: \text { Weralu } \\
\text { E: Ceylon olive }\end{array}$ & $\begin{array}{l}\text { Yellow-green group } \\
\text { N144-D }\end{array}$ \\
\hline 11 & Flacourtia indica (Burm. f.) Merr. & Flacourtiaceae & $\begin{array}{l}\text { S: Ugurassa } \\
E: \text { Governor's plum }\end{array}$ & $\begin{array}{l}\text { Red-purple group 59- } \\
\text { A }\end{array}$ \\
\hline 12 & Garcinia quaesita Pierre. & Clusiaceae & $\begin{array}{l}\text { S: Goraka } \\
\text { E: Garcinia }\end{array}$ & $\begin{array}{l}\text { Deep yellow-pink } \\
\text { group 39-C }\end{array}$ \\
\hline 13 & Limonia acidissima L. & Rutaceae & $\begin{array}{l}S: \text { Diwul } \\
E: \text { Wood Apple }\end{array}$ & $\begin{array}{l}\text { Gray-brown group } \\
200-B \text { (flesh) }\end{array}$ \\
\hline 14 & Morus alba L. & Moraceae & $\begin{array}{l}\text { S: Mulberry } \\
\text { E: Mulberry }\end{array}$ & $\begin{array}{l}\text { Yellow-blue group } \\
\text { N92-A }\end{array}$ \\
\hline 15 & Muntingia calabura L. & Muntingiacea & $\begin{array}{l}S: \text { Jam } \\
E: \text { Jamaican Cherry }\end{array}$ & $\begin{array}{l}\text { Yellow-green group } \\
144-B\end{array}$ \\
\hline 16 & Phyllanthus acidus L. Skeels & Euphorbiaceae & $\begin{array}{l}S: \text { Rata Nelli } \\
E: \text { Star gooseberry }\end{array}$ & $\begin{array}{l}\text { Yellow green group } \\
150-B\end{array}$ \\
\hline 17 & Phyllanthus embilica L. & Euphorbiaceae & $\begin{array}{l}S: \text { Nelli } \\
E: \text { Indian gooseberry }\end{array}$ & $\begin{array}{l}\text { Yellow-green group } \\
144-D\end{array}$ \\
\hline 18 & $\begin{array}{l}\text { Pouteria campechiana (Kunth) } \\
\text { Baehni. }\end{array}$ & Sapotaceae & $\begin{array}{l}\text { S: Lawulu } \\
\text { E: Canistel }\end{array}$ & $\begin{array}{l}\text { Yellow-orange group } \\
17-\mathrm{A}\end{array}$ \\
\hline 19 & Solanum nigrum L. & Solanaceae & $\begin{array}{l}\text { S: Kalukamberiya } \\
E: \text { Black Nightshade }\end{array}$ & $\begin{array}{l}\text { Violet-blue group } \\
\text { N92-C }\end{array}$ \\
\hline 20 & $\begin{array}{l}\text { Syzygium caryophyllatum L. } \\
\text { Alston }\end{array}$ & Myrtaceae & $\begin{array}{l}\text { S: Heen-Dan } \\
\text { E: - }\end{array}$ & $\begin{array}{l}\text { Violet-blue group } \\
\text { N92-C }\end{array}$ \\
\hline 21 & Syzygium cumini L. Skeels & Myrtaceae & $\begin{array}{l}S: \text { Ma-dan } \\
\text { E: Java plum }\end{array}$ & $\begin{array}{l}\text { Violet-blue group } \\
\text { N92-D }\end{array}$ \\
\hline
\end{tabular}

Note: Local name in Sinhala $(S)$ and in English $(E)$

\section{Determination of Total Phenol Content (TPC)}

The Folin-Ciocalteu's (FC) reagent assay (Yu et al., 2002) was adapted with minor modifications. Briefly, $20 \mu \mathrm{L}$ of sample was mixed with $100 \mu \mathrm{L}$ of
$2 \mathrm{~N} \mathrm{FC}$ reagent and $1.58 \mathrm{~mL}$ of distilled water, vortexed, allowed to stand at RT for 8 minutes, incubated for 30 minutes at RT after adding $300 \mu \mathrm{L}$ of $0.7 \mathrm{M}$ sodium carbonate. The absorbance of the mixture was measured (765 nm, Helios Omega UV - VIS spectrophotometer). Negative control was 
performed by adding methanol except the sample. Results were expressed as mg of gallic acid equivalents per gram dry weight of sample (mg GAE/g DW) by comparing with the standard calibration curve constructed using values of absorbance at $765 \mathrm{~nm}$ for different concentrations of gallic acid.

\section{Determination of 2,2-diphenyl-1- pycrylehydrazyl (DPPH)Radical Scavenging Activity}

The radical scavenging activity of fruit extracts was assessed using 2,2-diphenyl-1picrylhydrazylhydrate (DPPH) radical scavenging assay (Su et al., 2007) with some modifications. The sample $(0.2 \mathrm{~mL})$ was mixed with $1.8 \mathrm{~mL}$ of $0.1 \mathrm{mM}$ methanolic DPPH radical, left for an hour in the dark at RT and absorbance was recorded at 517 $\mathrm{nm}$. The negative control was prepared by adding $0.2 \mathrm{~mL}$ of methanol, instead of sample. Using the following equation, the radical scavenging activity (RSA) was calculated as percentage of discolouration of DPPH radical.

$$
\left.\mathrm{RSA} \%=1-\left(\mathrm{A}_{\text {sample }} / \mathrm{A}_{\text {control }}\right)\right\} \times 100
$$

Where, $A_{\text {sample }}$ is the absorbance of the sample and Acontrol is the absorbance of the control.

The results were expressed as $\mathrm{IC}_{50}$ values that denote the concentration of the sample required ( $\mathrm{g}$ of dry weight $/ \mathrm{mL}$ ) to scavenge $50 \%$ of DPPH radicals in the reaction medium.

\section{Determination of Total Antioxidant Activity (TAA)}

The ABTS cation radical scavenging assay (Zhou and $\mathrm{Yu}, 2004$ ) was used to determine TAA. To perform the assay $1.96 \mathrm{~mL}$ of stock (containing 2.5 mM ABTS and $2 \mathrm{mM}$ AAPH in 1:1 ratio) was mixed with $0.04 \mathrm{~mL}$ of the sample and absorbance was measured over six minutes at $1^{\text {st }}, 3^{\text {rd }}$ and $6^{\text {th }}$ minute at $734 \mathrm{~nm}$. In place of the sample, the stock was used as negative control. Results were expressed as percentage inhibition of ABTS radical cation over six minutes by calculating RSA using following formula.

$$
\mathrm{RSA} \%=\left\{1-\left(\mathrm{A}_{\text {sample }} / \mathrm{A}_{\text {control }}\right)\right\} \times 100
$$

Where, $A_{\text {sample }}$ is the absorbance of the sample and Acontrol is the absorbance of the control.

\section{Determination of Reducing Power (RP) of Fruit Extracts}

The ferric reducing antioxidant power (FRAP) assay (Benzie and Strain, 1996) was used with minor changes to determine reducing power (RP). The freshly prepared, pre-heated (at $37^{\circ} \mathrm{C}$ ) $1.5 \mathrm{~mL}$ of FRAP reagent was mixed with $0.5 \mathrm{~mL}$ of sample, vortexed for $30 \mathrm{~s}$, incubated for $4 \mathrm{~min}$ at RT and absorbance was measured (593 nm). The FRAP reagent was used as the negative control. The RP of samples was determined using the $\mathrm{FeSO}_{4} .7 \mathrm{H}_{2} \mathrm{O}(0$ $1 \mathrm{mM}$ ) calibration curve and results were expressed as $\mu \mathrm{mol}$ of ferrous sulphate equivalents (FSE) in gram of fruits on dry weight basis ( $\mu \mathrm{mol}$ of FSE/g DW).

\section{Determination of Total Monomeric Anthocyanin Content (TMAC)}

The $\mathrm{pH}$ differential method was adapted with slight modifications to determine the TMAC of lyophilized extracts (Lee et al., 2005). In brief, 1.8 $\mathrm{mL}$ of potassium chloride buffer ( $\mathrm{pH} 1$ ) and sodium acetate buffer ( $\mathrm{pH} 4.5$ ) were added separately into test tubes containing $0.2 \mathrm{~mL}$ of extracts, kept for 15 minutes at RT and absorbance was measured (520 $\mathrm{nm}$ and $700 \mathrm{~nm}$ ). The TMAC was calculated using the following formula and the results were expressed in milligrams of cyanidin-3-glucoside in gram of fruits on dry weight basis (mg C3G/g DW), as it is the most abundant anthocyanin pigment in the nature (Francis and Markarkis, 1989).

$$
\text { Cyanidin-3-glucoside }=\frac{\mathrm{A} \times \mathrm{MW} \times \mathrm{DF} \times 10^{3}}{\varepsilon \times \mathrm{L}}
$$

Where, A, MW, DF, L and $\varepsilon$ are absorbance values $\left\{(\text { A } 520-\mathrm{A} \text { 700 })_{\mathrm{pH} 1}-(\text { A 520-A 700 })_{\mathrm{pH} 4.5}\right\}$, molecular weight of C3G (449.2 g), dilution factor, path length (cm) and molar extinction co-efficient $(26,900)$, respectively.

\section{Determination of Vitamin C Content}

The titrimetric method 967.21 (AOAC, 2005), was performed to determine vitamin $C$ content and expressed in mg of ascorbic acid equivalents (AAE) per $100 \mathrm{~g}$ of fruits in fresh weight (mg AAE/100 g FW).

$$
\text { Vitamin C content }=\frac{\mathrm{B} 2 \times \mathrm{V} 1 \times \mathrm{Vt} \times 50 \times 100}{\mathrm{~B} 1 \times \mathrm{V} 1 \times 10 \times \mathrm{W}}
$$

Where, B1, B2, V1, Vt, 10, 50 and $\mathrm{W}$ are volumes of dye reacted with standard ascorbic acid solution, volume of dye reacted with sample, volume of standard ascorbic acid solution taken for titration, total volume of standard ascorbic acid solution, 
volume of sample taken to titration, total volume of sample prepared and weight of sample, respectively.

\section{Statistical Analysis}

Data were statistically analysed using SAS 9.1 statistical software. Analysis of variance and least significant difference tests were conducted to identify significant difference of vitamin C, TPC, TMAC and antioxidant efficacy (DPPH, AP and TAA) among the species. For ranking of fruit species standardized means were used ( $Z$ values). Correlation among the studied variables was tested using Pearsons correlation coefficient. Clustering of the species was done using complete linkage method for standardised variables. Statistical significance was declared at $\mathrm{p}<0.05$.

\section{RESULTS AND DISCUSSION}

\section{Total Phenol, Vitamin C and Total Monomeric Anthocyanin Contents}

The TPC of selected fruit species significantly varied from 1.3 to $104 \mathrm{mg} \mathrm{GAE} / \mathrm{g}$ of fruits on dry weight basis (DW) (Table 2). The highest TPC was observed in P. emblica, followed by A. marmelos and $M$. calabura, while $D$. ovoideum and $B$. motleyana showed the lowest TPC. In this study, it was found that TPC of extracts of coloured fruit species was higher than that of white fleshed fruits. It may be due to the presence of higher anthocyanin content in coloured fruits, which might have contributed to the TPC. The highest TPC of $P$. emblica could be due to high quantity of hydrolysable tannins in the fruit (Charoenteeraboon et al., 2010). Fruit extracts of $M$. calabura, $S$. nigrum, $C$. carandus, $S$. caryophyllatum and S. cumini, which are not commonly consumed by urban community possessed higher TPC values than some common underutilized fruit species namely L. acidissima and E. serratus.

Most of studied fruit species contained high TPC compared to commonly consumed fruits. The TPC of pineapple, mango, papaya and litchi were 0.479 , $0.56,0.576$, and $0.288 \mathrm{mg} \mathrm{GAE} / \mathrm{g}$, respectively (Luximon-Ramma et al., 2003), which was lower than the tested fruit extracts. The fruit extracts of P. emblica, A. marmelos, M. calabura, $P$. campechiana, S. nigrum and C. carandus exhibited high TPC than that of apple, which ranged between 2.11 and $3.41 \mathrm{mg} \mathrm{GAE} / \mathrm{g}$ on fresh weight basis $\mathrm{Wu}$ et al., 2004). The phenolic content varies with the cultivation practices, location, growing season and the maturity stage of the fruit (Kubola et al., 2011).
The highest vitamin C content was observed in $P$. emblica (523 mg AAE/100 g on fresh weight basis (FW) while the lowest was recorded in D. ovoideum (4.5 mg AAE/100 g on FW) (Table 2). Interestingly, all studied fruit species recorded higher vitamin $C$ values than that of yellow pear ( $1.6 \mathrm{mg} / 100 \mathrm{~g})$, red apple $(2.2 \mathrm{mg} / 100 \mathrm{~g})$ and green grapes (2.9 $\mathrm{mg} / 100 \mathrm{~g}$ ) (Tee et al., 1988). Some tropical fruits possess higher concentrations of bioactive compounds than temperate and sub-tropical fruits (Lule and Xia, 2012).

Anthocyanins are major phenolic compounds belonging to the flavonoid group and considered as one of the broadly distributed plant pigments with a wide range of colours (Elbe and Schwartz, 1996). There is an increasing interest in anthocyanin rich food as they possess anticancer, antioxidant, antiinflammatory and anti-diabetic activities (Nile et al., 2015). The highest TMAC was recorded in $S$. caryophyllatum ( $79 \mathrm{mg} \mathrm{C3G/g} \mathrm{DW)} \mathrm{followed} \mathrm{by} M$. alba, S. cumini, C. couliflora, C. carandas, respectively while least was in E. serratus, $M$. calabura and B. Motleyana (Table 2). It was impossible to find published research on anthocyanin content of locally available underutilized fruit species.

\section{Antioxidant Efficacy of Fruit Extracts}

Due to the complex and multifunctional nature of phytochemicals, they act as free radical scavengers, reducing agents, metal chelators and absorbers of ultraviolet radiation (Lü et al., 2010). Therefore, the antioxidant efficacy of food cannot be judged using any single method, thus multiple numbers of in-vitro assays need to be used to obtain precise information on antioxidant efficacy of fruit extracts. Therefore, DPPH, ABTS and FRAP assays were used in this study to determine antioxidant efficacy of lyophilized aqueous extracts of selected fruit species.

The highest $\mathrm{IC}_{50}$ values denote the lowest RSA, and B. motleyana $(7 \mathrm{~g} / \mathrm{mL})$ and P. emblica $(0.0004$ $\mathrm{g} / \mathrm{mL}$ ) possessed the highest and lowest IC $_{50}$ values, respectively (Table 3). The fruit extract of D. ovoideum which possessed lowest TPC, was not significant with the values of $A$. marmelos, $F$. indica, $C$. dichotoma and G. quaesita which showed a comparatively low $\mathrm{IC}_{50}$ value. It could be due to the scavenging ability of non-phenolic compounds in the fruit extracts of D. ovoideum.

The FRAP assay measures the reducing power of fruit extracts, by producing coloured ferrous tripyridyltriazine $\left(\mathrm{Fe}^{2+-} \mathrm{TPTZ}\right)$ from ferric tripyridyltriazine $\left(\mathrm{Fe}^{3+}\right.$-TPTZ) complex (Benzie and Strain, 1996). The reducing power of 
lyophilized aqueous fruit extracts ranged from the lowest in D. ovoideum (4.35 $\mu \mathrm{mol} \mathrm{FSE/g)} \mathrm{to} \mathrm{the}$ highest in P. emblica (155 $\mu \mathrm{mol} \mathrm{FSE/g)} \mathrm{(Table} \mathrm{3).}$ The fruit extracts of $S$. nigrum, M. calabura, $F$. indica, P. campechiana, G. quaesita and $S$. caryophyllatum recorded the highest reducing power after $P$. emblica.

Table 2: Total phenolic content (TPC), total monomeric anthocyanin content (TMAC) and vitamin C (Vit C) content of selected fruit species

\begin{tabular}{|c|c|c|c|c|}
\hline No. & $\begin{array}{l}\text { Selected Fruit } \\
\text { Species }\end{array}$ & $\begin{array}{l}\text { TPC } \\
\text { (mg GAE/g DW) }\end{array}$ & $\begin{array}{l}\text { TMAC } \\
\text { (mg C3G/g DW) }\end{array}$ & $\begin{array}{l}\text { Vit C } \\
\text { (mg AAE } / 100 \text { g FW) }\end{array}$ \\
\hline 1 & A. marmelos & $21.5 \pm 0.24^{b}$ & $0.82 \pm 0.04^{\text {hij }}$ & $71.5 \pm 0.93^{b}$ \\
\hline 2 & A. bilimbi & $11.8 \pm 0.21^{\mathrm{f}}$ & $1.94 \pm 0.19^{\mathrm{efgh}}$ & $49.3 \pm 0.09^{m}$ \\
\hline 3 & A. carambola & $6.4 \pm 0.07^{\mathrm{ij}}$ & $0.70 \pm 0.14^{\mathrm{ij}}$ & $21.7 \pm 0.01^{h}$ \\
\hline 4 & B. motleyana & $1.5 \pm 0.01^{n}$ & $0.29 \pm 0.04^{j}$ & $55.4 \pm 0.56^{d}$ \\
\hline 5 & C. carandas & $10.0 \pm 0.23^{\mathrm{g}}$ & $7.89 \pm 0.51^{d}$ & $10.1 \pm 0.23^{\mathrm{lm}}$ \\
\hline 6 & C. dichotoma & $5.9 \pm 0.27^{\mathrm{ijk}}$ & $0.75 \pm 0.05^{h i j}$ & $17.5 \pm 0.07^{\mathrm{i}}$ \\
\hline 7 & C. cauliflora & $4.6 \pm 0.06^{1}$ & $8.66 \pm 1.68^{d}$ & $21.8 \pm 0.33^{h}$ \\
\hline 8 & D. ovoideum & $1.3 \pm 0.02^{n}$ & $2.56 \pm 0.02^{\text {efg }}$ & $4.5 \pm 0.08^{\circ}$ \\
\hline 9 & D. discolor & $2.9 \pm 0.12^{\mathrm{m}}$ & $0.45 \pm 0.06^{\mathrm{ij}}$ & $39.2 \pm 0.45^{\mathrm{g}}$ \\
\hline 10 & E. serratus & $2.2 \pm 0.03^{\mathrm{mn}}$ & $0.29 \pm 0.03^{j}$ & $46.5 \pm 0.36^{f}$ \\
\hline 11 & F. indica & $14.4 \pm 0.18^{\mathrm{e}}$ & $1.67 \pm 0.23^{\text {fghi }}$ & $13.4 \pm 0.52^{\mathrm{k}}$ \\
\hline 12 & G. quaesita & $5.1 \pm 0.13^{\mathrm{kl}}$ & $2.94 \pm 0.07^{\mathrm{e}}$ & $38.9 \pm 0.43^{\mathrm{g}}$ \\
\hline 13 & L. acidissima & $6.3 \pm 0.17^{\mathrm{ijk}}$ & $2.67 \pm 0.29^{\mathrm{ef}}$ & $6.6 \pm 0.07^{n}$ \\
\hline 14 & M. alba & $5.2 \pm 0.16^{j \mathrm{kl}}$ & $46.69 \pm 0.14^{b}$ & $15.4 \pm 0.14^{j}$ \\
\hline 15 & M. calabura & $19.4 \pm 0.14^{c}$ & $0.31 \pm 0.07^{j}$ & $60.8 \pm 0.15^{c}$ \\
\hline 16 & P. acidus & $8.3 \pm 0.68^{h}$ & $0.75 \pm 0.13^{h i j}$ & $17.1 \pm 0.41^{\mathrm{i}}$ \\
\hline 17 & P. emblica & $103.7 \pm 1.53^{\mathrm{a}}$ & $2.98 \pm 0.37^{\mathrm{e}}$ & $523.1 \pm 1.29^{\mathrm{a}}$ \\
\hline 18 & P. campechiana & $15.7 \pm 0.42^{d}$ & $0.73 \pm 0.05^{\text {hij }}$ & $53.1 \pm 0.54^{\mathrm{e}}$ \\
\hline 19 & S. nigrum & $14.8 \pm 0.71^{\mathrm{de}}$ & $1.44 \pm 0.23^{\text {ghij }}$ & $11.2 \pm 0.15^{1}$ \\
\hline 20 & S. caryophyllatum & $8.0 \pm 0.13^{h}$ & $78.60 \pm 0.59^{\mathrm{a}}$ & $38.2 \pm 0.73^{g}$ \\
\hline 21 & S. cumini & $6.6 \pm 0.06^{i}$ & $12.71 \pm 0.34^{c}$ & $22.4 \pm 0.33^{h}$ \\
\hline
\end{tabular}

Data are presented as Mean \pm standard error, values with different letters in each column are significantly different at $\mathrm{p}<0.05$, DWdry weight basis, GAE - gallic acid equivalents, C3G - cyanidin-3-glucosode, AAE - ascorbic acid equivalents, FW- fresh weight basis 
Table 3: Reducing power (RP) and the $\mathrm{IC}_{50}$ value of selected fruit species

\begin{tabular}{|c|c|c|c|}
\hline & Selected Fruit Species & $\mathrm{IC}_{50}(\mathrm{~g}$ of $\mathrm{DW} / \mathrm{mL})$ & RP $(\mu \mathrm{mol} F S E / g$ DW $)$ \\
\hline 1 & A. marmelos & $0.05 \pm 0.01^{\mathrm{jklm}}$ & $33.59 \pm 1.57^{\mathrm{fg}}$ \\
\hline 2 & A. bilimbi & $5.18 \pm 0.82^{b}$ & $32.86 \pm 3.89^{\mathrm{g}}$ \\
\hline 3 & A. carambola & $0.74 \pm 0.02^{\mathrm{e}}$ & $18.60 \pm 2.29^{\mathrm{jk}}$ \\
\hline 4 & B. motleyana & $6.92 \pm 0.72^{\mathrm{a}}$ & $6.86 \pm 0.76^{\mathrm{mn}}$ \\
\hline 5 & C. carandas & $0.25 \pm 0.01^{h}$ & $38.89 \pm 2.80^{\text {ef }}$ \\
\hline 6 & C. dichotoma & $0.09 \pm 0.18^{\mathrm{jk}}$ & $10.13 \pm 1.46^{\mathrm{jk}}$ \\
\hline 7 & C. couliflora & $0.47 \pm 0.03^{\mathrm{f}}$ & $25.07 \pm 0.73^{\text {hi }}$ \\
\hline 8 & D. ovoideum & $0.08 \pm 0.01^{\mathrm{jkl}}$ & $4.35 \pm 0.14^{n}$ \\
\hline 9 & D. discolor & $1.06 \pm 0.34^{c}$ & $13.79 \pm 0.37^{\mathrm{kl}}$ \\
\hline 10 & E. serratus & $0.17 \pm 0.02^{i}$ & $10.20 \pm 0.87^{\operatorname{lm}}$ \\
\hline 11 & F. indica & $0.62 \pm 0.01^{\mathrm{jklm}}$ & $62.10 \pm 1.49^{c}$ \\
\hline 12 & G. quaesita & $0.10 \pm 0.02^{\mathrm{jk}}$ & $46.51 \pm 2.36^{\mathrm{d}}$ \\
\hline 13 & L. acidissima & $0.24 \pm 0.03^{h}$ & $29.55 \pm 2.39^{\mathrm{gh}}$ \\
\hline 14 & M. alba & $0.25 \pm 0.01^{h}$ & $30.21 \pm 0.62^{\mathrm{gh}}$ \\
\hline 15 & M. calabura & $0.03 \pm 0.01^{\mathrm{klm}}$ & $64.45 \pm 0.87^{\mathrm{c}}$ \\
\hline 16 & P. acidus & $0.91 \pm 0.03^{\mathrm{d}}$ & $17.52 \pm 2.38^{\mathrm{jk}}$ \\
\hline 17 & P. emblica & $0.0004 \pm 0.0^{\mathrm{m}}$ & $154.63 \pm 0.14^{\mathrm{a}}$ \\
\hline 18 & P. campechiana & $0.32 \pm 0.04^{\mathrm{g}}$ & $47.59 \pm 0.23^{d}$ \\
\hline 19 & S. nigrum & $0.29 \pm 0.04^{\mathrm{gh}}$ & $71.80 \pm 4.07^{\mathrm{b}}$ \\
\hline 20 & S. caryophyllatum & $0.02 \pm 0.02^{\operatorname{lm}}$ & $40.99 \pm 1.88^{\mathrm{e}}$ \\
\hline 21 & S. cumini & $0.11 \pm 0.02^{\mathrm{ij}}$ & $21.51 \pm 0.41^{\mathrm{ij}}$ \\
\hline
\end{tabular}

Data are presented as Mean \pm Standard error

FSE - Ferrous sulphate equivalents. Values with different letters in each column are significantly different at $\mathrm{p}<0.05$

In ABTS assay, the combined antioxidant activities of all constituents were assessed through radical quenching ability, since it is soluble in both aqueous and organic solvents and therefore can assess the efficacy of both lipophilic and hydrophilic antioxidants (Apak et al., 2007). The fruit extracts of $F$. indica, $M$. alba, P. emblica, $S$. caryophyllatum showed more than $80 \%$ of RSA (Figure 1) while $B$. motleyana and $P$. acidus recorded the least after 6 mins (Figure 2). Within the first minute of the reaction more than $50 \%$ of $\mathrm{ABTS}^{\circ+}$ in the reaction medium was scavenged by extracts of $M$. calabura, $S$. caryophyllatum, M. alba, P. emblica, F. indica, A. marmelos, E. serratus and $D$. discolour (Figure 1). While fruit extracts of $P$. campechiana showed $9.5 \%$ activity at the first minute, it finally reached to a maximum of $76.1 \%$. The extracts of $A$. marmelos, $S$. cumini and $D$. discolor showed equal antioxidant activities after six minutes (Figure 1). The extracts of P. acidus started to react with the radical after the first minute (Figure 2) and G. quaesita, one of the most common culinary agents in India and Sri Lanka 
(Rasha et al., 2015), recorded $28.1 \%$ of RSA which is not significant with that of $A$. bilimbi.

Fruit extracts of F. indica, M. alba, P. emblica, $S$. caryophyllatum, M. calabura, E. serratus, $P$. campechiana and D. discolor (Figure 1) and $C$. carandas, C. dichotoma, G. quaesita, A. bilimbi, $L$. acidissima, C. couliflora, P. acidus and B. motleyana (Figure 2) showed the same pattern of rate of reaction while reaching fairly constant levels of reaction after the third minute with different RSA values, indicating that they completed the reaction within three minutes achieving maximum RSA of each extract whereas $P$. campechiana (Figure 1), S. nigrum, A. carambola and D. ovoideum (Figure 2) showed a further increase of the reaction rate without reaching a constant after the third minute. This may be due to the different classes of antioxidative compounds present in extracts starting to react with $\mathrm{ABTS}^{\bullet+}$ radical after three minutes.

Both FRAP and ABTS assays rely on the hypothesis that redox reactions proceed very rapidly and complete the reactions within 4 and 6 minutes, respectively, however some polyphenols react slowly and require longer reaction time for detection (Prior et al., 2005). Therefore, underestimation of antioxidant capacity is possible with those assays. Thus single-point absorption endpoint is not sufficient to represent complete reaction. The DPPH and ABTS radical scavenging assays are based on the reduction of colour of DPPH and ABTS radical by the antioxidant, thus the presence of coloured compounds in the test material could interfere with absorbance. The FC assay measures total phenolics in the reaction medium, and the mechanism involved is oxidationreduction. Thus interference of other non-phenolic organic substances (ascorbic acid, organic acids, proteins and sugars) by reacting with FC reagent results in an overestimation. The radical scavenging assays such as ABTS, FRAP and DPPH are simple, rapid, inexpensive and do not require specialized equipment, thus are widely used (Prior et al., 2005). In this study, $\mathrm{pH}$ differential method was used to estimate total monomeric anthocyanin content based on the reversible colour change of monomeric anthocyanin pigment at $\mathrm{pH}$ of 1.0 (coloured) and 4.5 (colourless), whereas polymeric forms resistant to colour change and therefore are not included in the measurements (Lee et al., 2005).

\section{Ranking of Fruit Species, Clustering and Correlation Analysis}

Ranking sequences of fruits in terms of overall antioxidative activity was carried out according to the standardized values ( $\mathrm{Z}$ value) of TPC, DPPH, ABTS, FRAP, TMAC and vitamin C (Table 4). The highest mean value represents the highest overall antioxidant activity bearing the lowest rank (Table 4). Among the fruit extracts tested, P. emblica was characterized as the fruit with the highest overall antioxidative property (rank 1); this may be due to its higher antioxidative properties of all constituents. Interestingly, the second rank was obtained by the native fruit species $(S$. caryophyllatum) which has been red-listed by the World Conservation Monitoring Centre (1998). The extracts of M. alba, M. calabura and F. indica obtained the third, fourth and fifth ranks, respectively. The aqueous extracts of $B$. motleyana could be identified as the fruit species with the lowest overall antioxidant activity among selected fruit species.

To obtain a complete insight of the relationship among multiple variables, the use of multivariate analysis is more appropriate than using univariate statistical analysis and standard error values (Tomsone et al., 2012). Therefore, hierarchical cluster analysis was performed and a dendrogram was created based on the antioxidant efficacy (DPPH, ABTS and FRAP), TPC, TMAC and vitamin C values of selected fruit species. Figure 3 illustrates the dendrogram obtained with the Euclidean distances. The height of vertical line indicates the difference of similarity among clusters.

Based on the similarity levels from zero, it was possible to resolve four major clusters (Figure 3). The cluster one is simplifolious which consisted of only $P$. emblica which was dissimilar in all characteristics from other fruit species tested. This was due to its higher TPC, RSA (DPPH), reducing property (FRAP) and TAA of fruit extracts. Lyophilized extracts of $A$. blimbi and $B$.

motleyana exhibited the least TMAC and antioxidative properties among tested fruit species were grouped in cluster 2 at $29.7 \%$ similarity level. The cluster 3 was formed with those having the highest anthocyanin content (M. alba and $S$. caryophyllatum) with $45.9 \%$ similarity. Within the cluster 4, two main sub-clusters could be identified. The first sub-cluster of cluster 4 formed from 8 leaves with the common features of total antioxidant activity and anthocyanin contents. The sub cluster 2 of cluster 4 was grouped based on the level of total phenolic content, with remaining 8 species. A. carambola and C. dichotoma possess similarity in both TMAC and TPC at $93.6 \%$ while $L$. acidissima and C. cauliflora grouped at $95.6 \%$ for similar ABTS levels. 
The values of FRAP $(r=0.8999, \mathrm{p}<0.001)$ and vitamin $\mathrm{C}(r=0.9597, \mathrm{p}<0.001)$ showed a strong correlation with TPC (Table 5). The values of ABTS showed a significant negative correlation with DPPH radical scavenging activity. FRAP showed significant positive correlation with ABTS. It was because, the redox potential of $\mathrm{Fe}^{3+}-\mathrm{TPTZ}$ and $\mathrm{ABTS}^{+\bullet}$ is comparable to each other, thus similar compounds react in both assays (Prior et al., 2005). Vitamin C has significant positive correlation with FRAP and TPC. Values of TMAC did not correlate with any of the parameters tested.
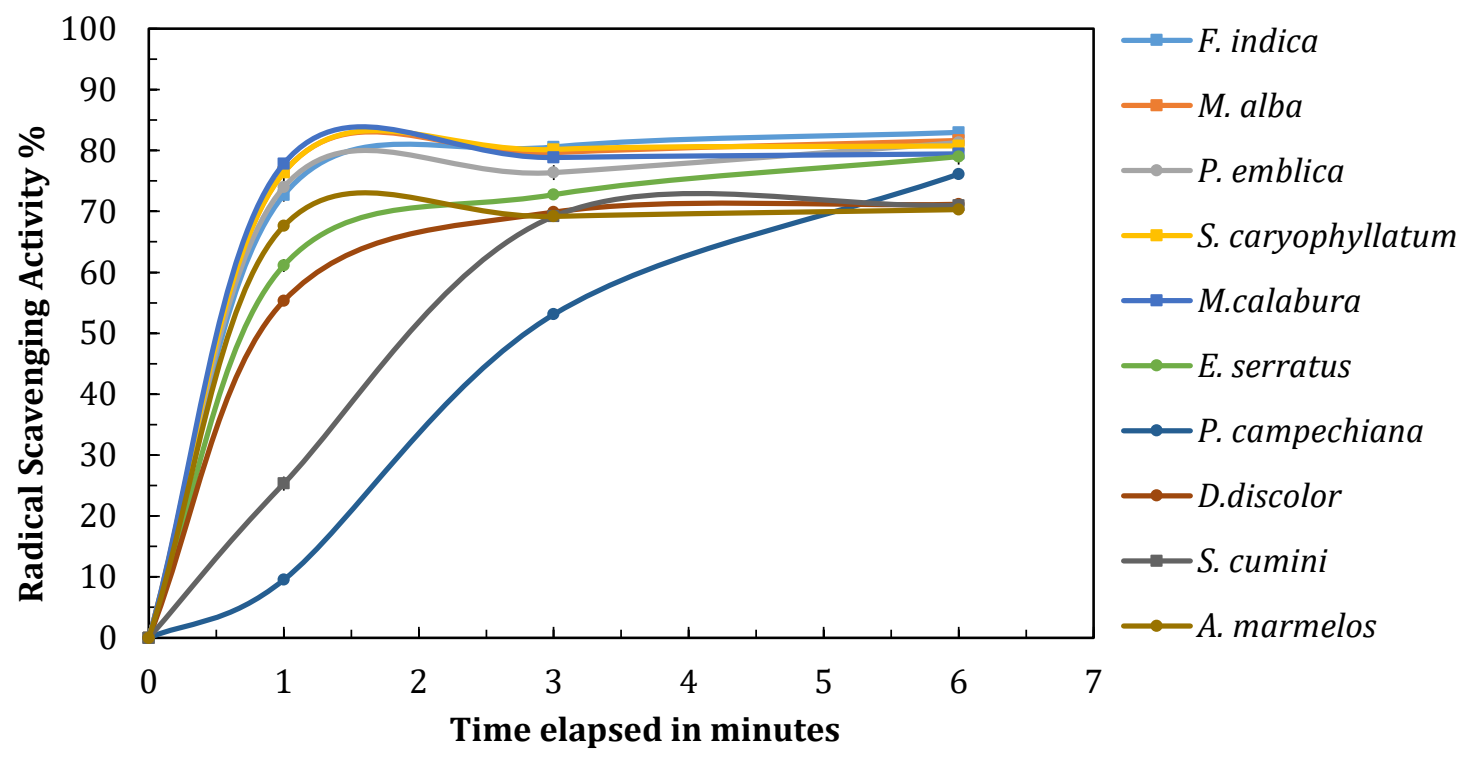

Figure 1: Radical scavenging activities over six minutes (fruit species $6^{\text {th }}$ minute)

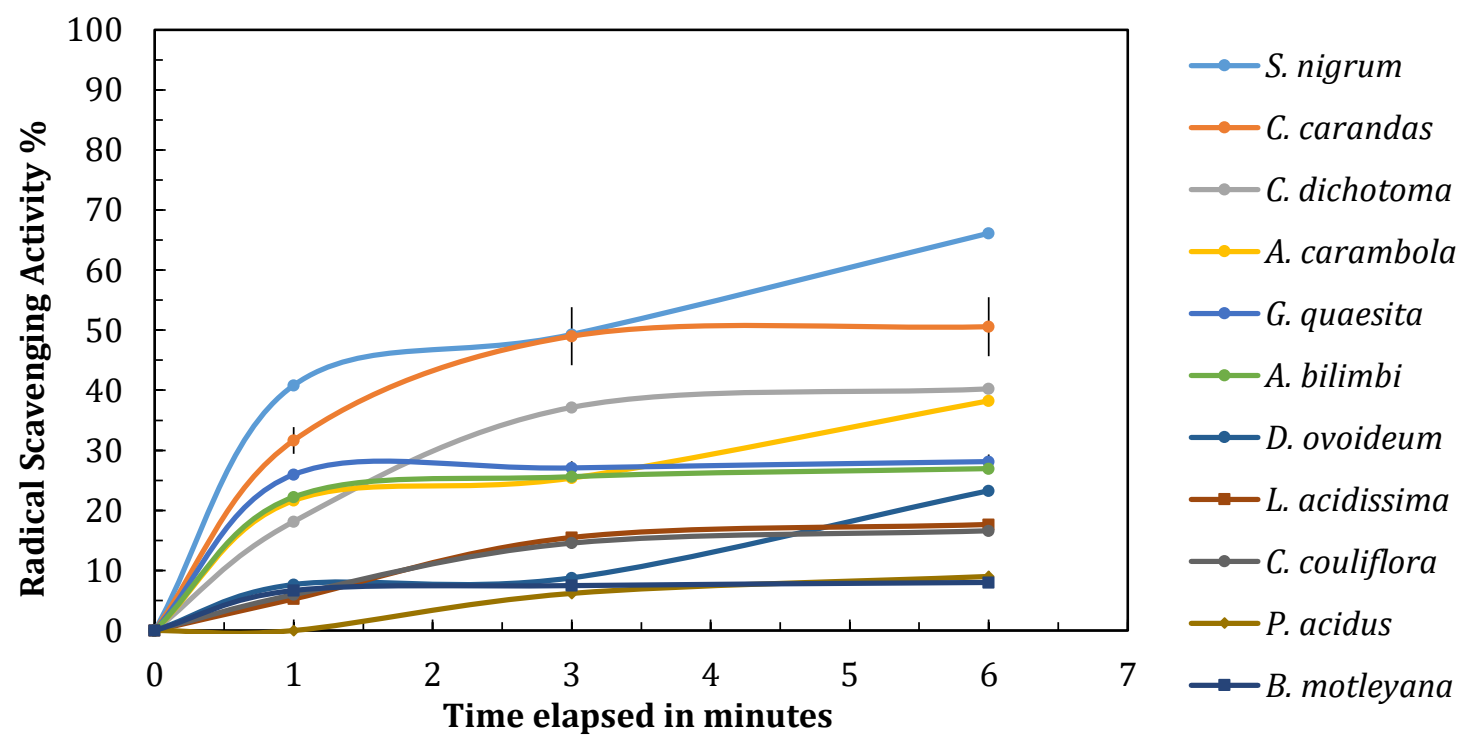

Figure 2: Radical scavenging activities over six minutes (fruit species possessing $<70 \%$ of RSA at $6^{\text {th }}$ minute) 
Table 4: Standardized values ( $\mathrm{Z}$ values) and ranks for antioxidant properties

\begin{tabular}{|c|c|c|c|c|c|c|c|c|c|}
\hline & \multirow{2}{*}{$\begin{array}{l}\text { Selected Fruit } \\
\text { Species }\end{array}$} & \multicolumn{6}{|c|}{$\mathrm{Z}$ values of antioxidant properties } & \multirow{2}{*}{ Mean } & \multirow{2}{*}{ Rank } \\
\hline & & Vit C & TPC & IC $_{50}$ & FSE & TMAC & TAA & & \\
\hline 1 & A. marmelos & 0.80 & 1.78 & 2.00 & -0.50 & -1.82 & 2.97 & 0.87 & 8 \\
\hline 2 & A. bilimbi & -1.80 & -0.29 & -11.19 & -0.60 & -1.55 & -4.19 & -3.27 & 20 \\
\hline 3 & A. carambola & -1.28 & -1.43 & 0.21 & -2.58 & -1.85 & -2.32 & -1.54 & 15 \\
\hline 4 & B. motleyana & 0.13 & -2.48 & -15.67 & -4.21 & -1.95 & -7.31 & -5.25 & 21 \\
\hline 5 & C. carandas & -1.76 & -0.66 & 1.48 & 0.23 & -0.12 & -0.29 & -0.18 & 10 \\
\hline 6 & C. dichotoma & -1.45 & -1.53 & 1.89 & -3.75 & -1.84 & -1.99 & -1.45 & 14 \\
\hline 7 & C. cauliflora & -1.27 & -1.81 & 0.93 & -1.68 & 0.07 & -5.89 & -1.61 & 16 \\
\hline 8 & D. ovoideum & -2.00 & -2.52 & 1.91 & -4.56 & -1.40 & -4.79 & -2.23 & 18 \\
\hline 9 & D. discolor & -0.55 & -2.18 & -0.59 & -3.25 & -1.91 & 3.11 & -0.89 & 13 \\
\hline 10 & E. serratus & -0.24 & -2.32 & 1.68 & -3.74 & -1.95 & 4.41 & -0.36 & 11 \\
\hline 11 & F. indica & -1.62 & 0.26 & 1.96 & 3.45 & -1.62 & 5.06 & 1.25 & 5 \\
\hline 12 & G. quaesita & -0.56 & -1.71 & 1.88 & 1.29 & -1.31 & -3.99 & -0.73 & 12 \\
\hline 13 & L. acidissima & -1.91 & -1.46 & 1.49 & -1.06 & -1.37 & -5.72 & -1.67 & 17 \\
\hline 14 & M. alba & -1.54 & -1.68 & 1.49 & -0.97 & 9.24 & 4.84 & 1.90 & 3 \\
\hline 15 & M. calabura & 0.36 & 1.33 & 2.05 & 3.78 & -1.94 & 4.48 & 1.68 & 4 \\
\hline 16 & P. acidus & -1.47 & -1.02 & -0.22 & -2.73 & -1.84 & -7.15 & -2.41 & 19 \\
\hline 17 & P. emblica & 19.68 & 19.28 & 2.12 & 16.29 & -1.30 & 4.78 & 10.14 & 1 \\
\hline 18 & P. campechiana & 0.04 & 0.55 & 1.30 & 1.44 & -1.84 & 3.93 & 0.90 & 7 \\
\hline 19 & S. nigrum & -1.72 & 0.36 & 1.37 & 4.80 & -1.67 & 2.28 & 0.90 & 6 \\
\hline 20 & S. caryophyllatum & -0.59 & -1.08 & 2.08 & 0.53 & 16.93 & 4.69 & 3.76 & 2 \\
\hline 21 & S. cumini & -1.25 & -1.38 & 1.84 & -2.18 & 1.05 & 3.08 & 0.19 & 9 \\
\hline
\end{tabular}

VitC - vitamin C, TPC - total phenolic content, $\mathrm{IC}_{50}$ - $50 \%$ of radical scavenging activity, FSE - reducing power in ferrous sulphate equivalent, TMAC - total monomeric anthocyanin content and TAA - total antioxidant activity.

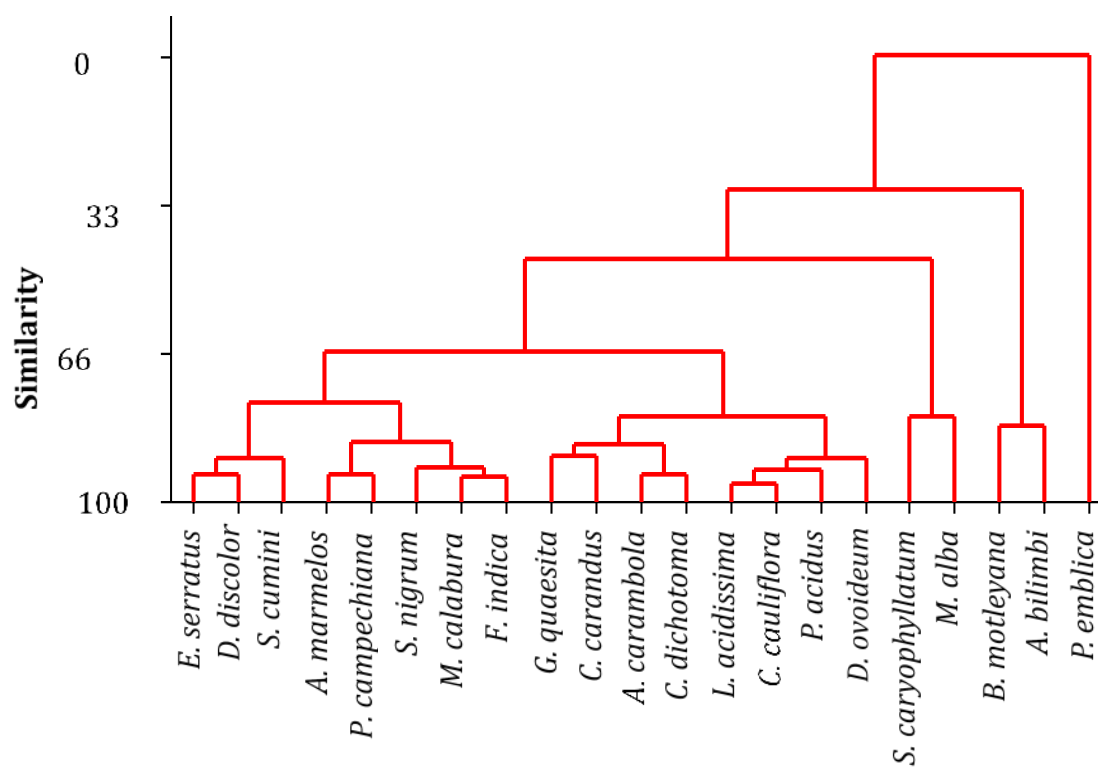

Figure 3: Dendrogram with complete linkage and Euclidean distance for values of TPC, IC ${ }_{50}$, FSE, TAA, TMAC and vitamin $C$ of selected fruit species 
Table 5: Strengths of the relationships among TPC, DPPH, FRAP, ABTS, Vitamin C and TMAC

\begin{tabular}{llrrrrr}
\hline & & TPC & \multicolumn{1}{c}{ DPPH } & FRAP & ABTS & \multicolumn{1}{c}{ TMAC } \\
\hline TPC & $r$ & 1.0000 & & & & \\
& $\mathrm{p}$ & & & & & \\
DPPH & $r$ & -0.1554 & 1.0000 & & & \\
& $\mathrm{p}$ & 0.5013 & & & & \\
FRAP & $r$ & 0.8999 & -0.2485 & 1.0000 & & \\
& $\mathrm{p}$ & $<.0001$ & 0.2773 & & & \\
ABTS & $r$ & 0.3438 & -0.4746 & 0.4542 & 1.0000 & \\
& $\mathrm{p}$ & 0.1270 & 0.0297 & 0.0386 & & \\
TMAC & $r$ & 0.0933 & -0.1609 & 0.0021 & 0.3204 & 1.0000 \\
& $\mathrm{p}$ & 0.6876 & 0.4859 & 0.9929 & 0.1567 & \\
Vitamin C & $r$ & 0.9597 & -0.0146 & 0.7928 & 0.2319 & -0.1166 \\
& $\mathrm{p}$ & $<.0001$ & 0.9499 & $<.0001$ & 0.3118 & 0.6148 \\
\hline
\end{tabular}

$r$ - Correlation coefficient, p- probability value

\section{CONCLUSIONS}

There is a wide variation in the vitamin C, TPC, TMAC, and antioxidant efficacy of selected underutilized fruit species. Phyllanthus emblica has the highest overall antioxidant properties followed by Syzygium caryophyllatum, Morus alba, Muntingia calabura and Flacourtia indica.

The dendrogram obtained for tested fruit species showed that externally different fruit species are sharing same internal antioxidative characteristics. P. emblica cannot be substituted by any other fruit species as it dissimilar in all characteristics from

\section{REFERENCES}

AOAC International (2005). Official Methods of Analysis, $18^{\text {th }}$ ed. AOAC International, Washington, DC. USA.

Apak, R., Güçlü, K., Demirata, B., Özyürek, M., Çelik. S. E., Bektaşoğlu, B., Berker, K. I. and Özyurt, D. (2007). Comparative evaluation of various total antioxidant capacity assays applied to phenolic compounds with the CUPRAC assay. Molecules. 12, 1496-1547.

Benzie, I.F.F. and Strain, J. J. (1996). Ferric reducing ability of plasma (FRAP) as a measure of other tested fruit species. The correlation analyses indicated that significant, positive, strong correlation between TPC, vitamin C and FRAP values and between ABTS and FRAP values. The knowledge disseminated through this study will promote the utilization, cultivation, and commercialization of these species.

\section{ACKNOWLEDGEMENTS}

The authors acknowledge the Postgraduate Institute of Agriculture, University of Peradeniya for the financial support provided through the research facilitation fund (RFF).

"antioxidant power": the FRAP assay. Analytical Biochemistry. 239(1), 70-76.

Brecht, J. K., Ritenour, M.A., Haard, N.F. and Chism G.W. (2008). Postharvest Physiology of Edible Plant Tissues. pp 975-1049, in Srinivasan, D., Parkin, K. L and Fennema, O. R. (ed.). Fennema's Food Chemistry. $4^{\text {th }}$ Edition. CRC Press, Taylor and Francis Group, Boka Roton, FL, USA

Charoenteeraboon, J., Ngamkitidechakul, C., Soonthornchareonnon, N., Jaijoy, K. and Sireeratawong, S. (2010). Antioxidant activities of the standardized water extract from fruit of Phyllanthusemblica Linn. Songklanakarin Journal of Science \& Technology. 32(6), 599604. 
Elbe J.H. and Schwartz S.J. (1996). Colorants, pp $651-722$ in Fennema 0. R. (ed). Food Chemistry. Marcel Dekker, Inc. New York. NY, USA.

Francis, F.J. and Markarkis, P.C. (1989). Food colorants: anthocyanins, critical review. Food Science and Nutrition. (4), 273-314.

Heinonen, I.M. and Meyer, A.S. (2002). Antioxidants in Fruits, Berries and Vegetables. pp 23-51, in Jongen, W. (ed.). Fruit and Vegetable Processing Improving Quality. Woodhead Publishing limited, Boka Roton, FL, USA.

Kubola, J., Siriamornpun, S. and Meeso, N. (2011). Phytochemicals, vitamin $\mathrm{C}$ and sugar content of Thai wild fruits. Food Chemistry. 126, 972-981.

Lee, J., Robert, W.D. and Ronald, E.W. (2005). Determination of total monomeric anthocyanin pigment content of fruit juices, beverages, natural colorants, and wines by the $\mathrm{pH}$ differential method: collaborative study. Journal of AOAC International. 88(5), 12691278.

Lee, S.K. and Kader, A.A. (2000). Preharvest and postharvest factors influencing vitamin $\mathrm{C}$ content of horticultural crops. Postharvest Biology and Technology. 20, 20-220.

Leong, L.P. and Shui, G. (2001). An investigation of antioxidant capacity of fruits in Singapore markets. Food Chemistry. 76(1), 69-75.

Lü, J-M., Lin, P.H., Yao, Q. and Chen, C. (2010). Chemical and molecular mechanisms of antioxidants: experimental approaches and model systems. Journal of Cellular \& Molecular Medicine. 14(4), 840-860.

Lule, S.U. and Xia, W. (2012). Phytochemicals and Bioactive compounds in Tropical and subtropical fruits. pp 53-70 In Siddiq, M., Ahmed, J., Lobo, M. G. and Ozadali, F. (ed.). Tropical and Subtropical Fruits Postharvest physiology, Processing and Packaging. John Wiley \& Sons, Inc. Hoboken, NJ, USA.

Luximon-Ramma, A., Bahorun, T. and Crozier, A. (2003). Antioxidant actions and phenolic and vitamin $C$ contents of common Mauritian exotic fruits, Journal of the Science of Food and Agriculture. 83, 496-502.

Manach, C., Scalbert, A., Morand, C., Rèmèsy, C. and Jimènez, L. (2004). Polyphenols: food sources and boavailability. American Journal of Clinical Nutrition. 79, 727-747.

Nile, S.H., Kim, D.H. and Keum, Y.S. (2015). Determination of anthocyanin content and antioxidant capacity of different grape varieties. Ciênciae Têcnica Vitivinicola. 30(2), 60-68.

Prior, R.L., Wu, X. and Schaich, K. (2005). Standardized methods for the determination of antioxidant capacity and phenolics in foods and dietary supplements. Journal of Agricultural and Food Chemistry. 53, 4290-4302.

Rasha, H.M., Salha, A., Thanai, A. and Zahar. A. (2015). The Biological importance of Garcinia Cambogia: A review. Journal of Nutrition \& Food Sciences. S5: 004. doi:10.4172/21559600.S5-004

Rice-Evans, C., Miller, N. and Paganga, G. (1997). Antioxidant Properties of phenolic compounds. Trends in Plant Science. 2(4), 152-159.

Rossi, A., Serraino, I., Dugo, P., Di-Paola, R., Mondell, L., Gerovese, T., Morabito, D., Dugo, G., Sautebin, L., Caputi, A.P. and Cuzzcrea, S. (2003). Protective effects of anthocyanins from blackberry in a rat model of acute lung inflammation. Free Radical Research. 37, 891900.

Rutkowski, M. and Grzegorczyk, K. (2007). Modifications of spectrophotometric methods for antioxidative vitamins determination convenient in analytic practice. Acta Scientiarum Polonorum Technolgia Alimentaria. 6(3), 17-28.

Su, L., Yin, J.J., Charles, D., Zhou, K., Moore, J. and Yu., L. (2007). Total Phenolic contents, chelating capacities and radical-scavenging properties of black peppercorn, nutmeg, rosehip, cinnamon and oregano leaf. Journal of Food Chemistry.100, 990-997.

Tee, E.S., Young, S.I., Ho, S.K. and Mizura, S (1988). Determination of vitamin $\mathrm{C}$ in fresh fruits and vegetables using the dye-titration and microfluorometric methods. Pertanika. 11(1), $39-44$.

Tomsone, A., Kruma, Z., Alsina, I. and Lepse, L. (2012). The application of hierarchical cluster analysis for classifying horseradish genotypes (Armoracia rusticana L.) roots. Chemine Technologija. Nr. 4(62), 52-56. 
World Conservation Monitoring Centre (1998). Syzygiumcaryophyllatum. The IUCN red list of threatened species 1998:e.T38036A10094391. http://dx.doi.org/10.2305/IUCN.UK.1998.RLT S.T38036A10094391.en

Wu, X., Beecher, G., Holden, J., Haytowitz, D., Gebhardt, S., and Prior, R. (2004). Lipophilic and hydrophilic antioxidant capacities of common foods in United States. Journal of Agricultural \& Food Chemistry. 52, 4026-4037.
Yu, L., Perret, J. and Davy, B., Wilson, J. and Melby, C.L. (2002). Antioxidant properties of cereal products. Journal of Food Science. 67(7), 26002603.

Zhou, K. and Yu, L. (2004). Antioxidant properties of bean extracts from Trego wheat grown at different locations. Journal of Agricultural \& Food Chemistry. 52(5), 1112-1117. 